JUSTYNA JAJSZCZOK

Uniwersytet Śląski w Katowicach

\title{
The Last Day and Brexit: Delusions of Future Past
}

Andrew Hunter Murray published his debut novel The Last Day in February 2020, a month before the official announcement of the COVID-19 pandemic but four years into the prolonged Brexit negotiations. Set in 2059, with flashbacks to 2020 and 2029, it tells a story of an unwilling heroine, a sea currents specialist Ellen Hopper, who learns of the government conspiracy and genocidal plans, all against the backdrop of the larger apocalypse: of the spinless Earth, which-due to the gravitational pull of a passing-by white dwarf star-slows and eventually stops revolving, eternally locked in the same position opposite the Sun. While the novel could be seen as premonitory in terms of a disease-related cataclysm (e.g., the Stop leads to a number of plagues, including the thawing of smallpox from Siberian permafrost (Murray 39)), it is much more strongly influenced by the social and political atmosphere surrounding the 2016 Leave vote and its repercussions. The author himself states that the idea for the novel arose half a year after the vote but that its Brexit parallels are coincidental rather than intentional: "So much of this was not really in the air when I started writing the book and since then we've had things like the Windrush scandal and all of these other stories, so I think there are parallels" (qtd. in Barry 2020). While clearly "Brexit-y," The Last Day owes a lot to its literary predecessors. The aim of the present paper, therefore, is to compare Murray's novel to narrative traditions from which it draws and demonstrate how, by following them, it cautions against entertaining, let alone fulfilling the dark Brexit fantasy. 


\section{Early Science-Fiction}

Murray's eco-dystopia is reminiscent of such texts as Jack London's The Iron Heel (1907), especially in terms of class-based exploitation themes, and Jules Verne's 1889 Sans dessus dessous (Topsy-Turvy), in which three entrepreneurs conspire to remove the tilt of the Earth's axis by means of cannons, but it is mostly indebted to H. G. Wells's 1897 short story “The Star.” Just like in The Last Day, here too a celestial body, this time a comet, narrowly misses the Earth, and its passing brings with it a number of apocalyptic events: "Earthquakes, volcanic outbreaks, cyclones, sea waves, floods, and a steady rise in temperature" (Wells 650). Told from the perspective of Martian astronomers, in style suggestive of a biblical parable, it is a tale of a star that wreaks havoc on Earth (even, for a moment, giving an impression of stopping the planet's rotation), which closely resembles the white dwarf star that brings doom to Murray's Earth in the fictional May 2020, beginning the Slow. Much like the majority of Wells's work, "The Star" can be categorised as innovative in terms of science-based space disaster; nonetheless, it contains reworkings of themes already present in popular literature of the time. Ailise Bulfin notes that its storyline, in which an exasperated scientist tries to warn the public of the danger, only to be mocked and derided, was a familiar trope by the end of the century (Bulfin 2015a: 93). Employing a gesture that has become typical of science fiction, in the guise of future catastrophe, Wells offers a damning commentary of the contemporary world and the ills and political crises it must contend with.

Wells's story conveniently ends before the post-near-apocalypse rebuilding of societies but leaves its readers with a strong suggestion of utopian cooperation: "But of the new brotherhood that grew presently among men, of the saving of laws and books and machines, ..., this story does not tell" (Wells 655). Having performed its duty: to inspire existential dread in their readers and to prepare them for the possible disasters to come, the story trails off in an anti-climax. Figuratively speaking, Murray picks it up where Wells has left it and composes its much darker sequel. At first, similarly to "The Star," as the Earth's revolutions become gradually slower, The Last Day offers some hope as the world seems to unite in the face of the threat:

There had been a final flourish of international cooperation when it seemed the world might end up with six-month days and nights-promises of food supplies shipped back and forth, a grand new planetary bargain, a dawning era of global collaboration as never seen before. (Murray 38) 
However, this optimism is very short-lived, because it soon becomes evident that the Slow will turn into the Stop and "[t]he new barriers of daylight and darkness [are] being established in perpetuity" (38). Facing new reality, people resort to old tricks and strategies of survival, abandoning noble but impractical ideals of cooperation and brotherhood.

\section{Future Peril Fiction}

Unlike Verne's or London's texts, however, Wells's short story can also be classified as belonging to the popular (or populist) genre of British fiction of the late nineteenth and early twentieth centuries, denoted variously as future-war fiction, invasion literature, or "invasion-scare tales" (Matin 2011: 802); for the purposes of this essay, I will refer to them as future peril stories. Now seen as "a paranoid literary phenomenon" (Bulfin 2015b: 482), some present "natural disaster as the mode of catastrophe," but most of these tales envisage a spectrum of possible "catastrophes of a man-made and military nature, including global wars, invasion, nationalist uprisings, domestic revolutions, superweapons, and manufactured plagues" (Bulfin 2015a: 83). Their agenda was to fulfil a very specific political function: they were supposed to shake the indolent and complacent society into vigilance by means of presenting imaginary but possible scenarios in which England was to be attacked by surprise by various enemies and subdued with ease. The stories were operating on baseless assumptions but reflected genuine invasion anxieties, and-as they induced in the public a sense of persistent but vague catastrophising, combined with very distinct isolationism and racial superiority-they took advantage of "a cultural atmosphere that was a breeding ground for fears and antipathies" (Matin 2020: 86).

Honing blunted patriotism into sharp nationalism, these tales also made a great deal of such ephemeral values as imperial loyalty and devotion of the colonies (Matin 2011: 809), in which standing in defence of the Crown and the imperial way of life was presented as a patriotic duty of every subject. While clearly alarmist, their lofty message allowed for creating an aspirational vision of social advancement for those hitherto disadvantaged in terms of class and opportunity; e.g., young lower-middle-class men were readily swallowing propaganda of glorious duty spewed by their "betters" in the belief that loyal service would pay dividends in the future (Keep 10). To some extent, this literary campaign prepared the groundwork for rising social acceptance of drastic measures suggested in fiction: sealing the borders, expelling "foreign elements," and widespread surveillance-all in the name of national security. 
The hallmarks of invasion literature, i.e. overt xenophobia and absolute isolationism, are reworked with ruthless determination in The Last Day. The moment it becomes apparent that Britain has lucked out and landed in the Goldilocks Zone-in the area between perpetual darkness and frost and perpetual day and scorching heat-waves of immigration begin to hit its shores, trying to reach the only land that still promises a chance of survival. Seeing their island "on the brink of collapse" and being "totally overrun" (Murray 330), the British government come up with the barbaric "Immigration Emergency" plan: to have the country completely sealed in. The relevant governmental document proposes

that the newly engorged Royal Navy should sink any foreign vessels that entered within a ten-mile zone, irrespective of the nature of the boat. Civilian, military, industrial, trafficker, refugee. Everything. Including any boats flying colours of allies, and any nonmilitary British ships. (Murray 328)

Drawing on the strategies employed in the Suez Crisis of 1956, when Egyptian authorities blocked the Canal by sinking vessels in it, the British decide to isolate themselves by physically blocking access to their borders. Moreover, to prevent any further refugee attempts, they destroy all European and northern African ports and boats on the Warmside: "The attack was ordered to take place over three consecutive days, to minimize the number of vessels that would survive. No warnings were to be given to civilians in advance of the raids" (Murray 329).

In the course of a conversation between the protagonist, Hopper, and Thorne, her university tutor and, as it turns out, the architect of this strategy, we learn that in the fight for the Tidal Defence Zone, an estimated ten million people have lost their lives, including Hopper's mother. Thorne deflects his student's accusation of genocide as a matter of security and proclaims: "We believed-I believed - those were the only two options. Barbarity or collapse" (Murray 331). Deflection, in general, seems to be the key strategy of this administration: to divert attention from its controversial security solutions, it launches a vast propaganda machine. National newspapers, the only media surviving the Stop, print good news exclusively:

A new factory each month .... Each week more farmland under the harrow, each year more schools, more roads, more food. Two years ago, a new railway line. The Great British Resurgence was well under way. ... [T] $]$ he dispatches remained optimistic. ... They weren't strictly true, of course. (Murray 17) 
The public, concerned with the mundane issues of food and shelter, is thus insidiously brainwashed, steadily developing a kind of siege mentality according to which everyone can be a potential refugee trying to invade insulated Britain and steal their resources.

\section{Happy Brexit Day}

Images of a complete breakdown of cooperation, going it alone, and shameless xenophobia, so typical of future peril literature and so prevalent in The Last Day, are unmistaken harbingers of Brexit. Numerous critics and commentators (e.g., Kehinde Andrews, Sathnam Sanghera, Anshuman A. Mondal, and Fintan O'Toole) point out how the language of taking back control and making Britain great again assumes the past existence of a proud, homogenous country very far from its historical truth. The body of research that has come out of the Brexit conundrum broadly identifies two areas or ideas that had shaped the outcome of the referendum and have influenced the political discourse since: the issue of sovereignty and the issue of immigration. These two thorny problems are disturbingly exemplified in the homemade posters celebrating "Brexit Day" put out in a Norwich tower block in February 2020 (Turnnidge 2020). While words such as, "[w]e do not tolerate people speaking other languages than English in the flats," and the delicious irony of some "true patriot" writing, "[w]e are now our own country again and the Queens [sic] English is the spoken tongue here" made the photograph of the poster go viral, the dangerous sentiment of this message is visible elsewhere. The authors, believing to be speaking for other like-minded people, suggest that if immigrants want to speak their mother tongues, they are not just supposed to go home-a slogan so hackneyed it almost blends in the white noise-but to "let British people live here ... [so that they] can return to what was normality before you infected this once great island," and to "evolve or leave." The "normality" professed in the poster as common knowledge is fiction, a myth instilled in the collective consciousness of Britons as a result of either, as Sathnam Sanghera proposes, "selective amnesia" (2020) or, as Sally Tomlinson asserts, as an intentional strategy of creating wilful ignorance starting with school curriculums (Tomlinson 63-89).

The bilious rage clear in the poster finds its parallel in a scene in The Last Day, when Hopper witnesses "the Winnow." In this monthly ceremony, a crowd of people are ceremoniously marched through the main artery of the city_ “To show other crooks what's coming to them" (Murray 99) - to be shipped out to the Breadbasket: an area of land in northern Europe, totally under British control, where it is still possible to cultivate the land and grow grain. Hopper, 
having spent a long time researching currents on the rig in the Atlantic, does an impromptu vox pop during the ceremony and asks one of the spectators who the people being winnowed are. The man's answer betrays undisguised affinity with sentiments expressed by "true patriots" of the Leave side:

"Criminals. Pris'ners, foreigners, es-caypees. Don't you worry, they deserve it, I can guarantee you that. They deserve everything they get."

$\cdots$

"You don't like it, you can join them. The foreigners all cheated their own people to get here. Left their families behind, most of them. And without them working away, you don't get your food, miss. You don't look like you refuse your bread."

"Scum. Not even got any shoes, some of them. And they steal. Scum."

Hopper observes a throng of people of various ages, nationalities and ethnicities being refused stay, labelled criminals, and forced into labour camps to provide food for the deserving (i.e., native) inhabitants of the island, while the brainwashed public derides them openly. Apart from obvious Second World War allusions, this bears more than a passing resemblance to the refugee crisis of 2015 and the British response to it. David Cameron, the Prime Minister at the time, seemed to have no qualms talking about "a swarm of people coming across the Mediterranean, seeking a better life, wanting to come to Britain" and making promises that "everything that can be done will be done to make sure our borders are secure and make sure that British holidaymakers are able to go on their holidays" (qtd. in Mukherjee 74). The confrontation of people's fight for survival with the inconvenience of holidaymakers in Cameron's words is jarring not just because he assumes a general acceptance of the false equivalence of the problems of these two groups of people. More telling is that his words betray a superiority of attitude, clearly a post-imperial hang-up, in which it goes without saying that the British are allowed more, including entering other countries whenever they please, without sparing a second to think of extending the same courtesy to others.

\section{Past Perfect, Future Conditional}

In Empireland, Sanghera notes that, although it seems to be an obvious route of exploration, imperial interpretation of Brexit may be almost too convenient 
an explanation. Due to what he calls selective amnesia, views of the grandness of the empire cannot be seen as a tool of national cohesion, as such ideas as patriotism, historical identity, and supremacy are too messy to mesh together without friction. Trouble defining what the empire stood and stands for, what it actually was (is) and how to identify (with) it leads to an incoherent collection of ideas rather than a fixed point of reference. National identity works as a tool of integration but only insofar as its white supremacist underpinnings are concerned: the at-home-ness Brexit promises does not include ethnicities present in contemporary Britain because, not in spite of, the empire. Selective amnesia allows for hyping the myths which reinforce propagandist messages and downplay any inconvenient facts (Sanghera).

The isolationism of Brexiteers harks back to the fantasy past of imperial ideals when the world was arranged justly, and everyone got exactly what they deserved. This make-believe world of grand narratives bears a striking affinity to its late-Victorian and Edwardian counterpart, in which fictional and alarmists calls to arms against (in)visible enemies served as tools of social cohesion-but only for the elite who benefited from this justness and righteous deservedness. Murray fulfils these fantasies. His novel gives the Brexiteers the Britain of the imaginary past they so long for. But this fantasy is hollow. The touted "splendid isolation" of Nigel Farage and Boris Johnson (Rau 39) is positively Orwellian: no satellites, no internet, no freedom-and not just of movement. The plot of The Last Day is the realisation of the dream without thinking of or caring about its consequences. In many ways, the Stop is like Brexit; the former, having started in May 2020, achieves its final stage in March 2029; the latter formally began in June 2016 and, as for now, does not seem to have reached its conclusion. Of course, people in the novel do not vote to have an ecological disaster happen to them, but the logic behind supporting self-harming policies is present in both fictional and actual Britain. Anshuman A. Mondal notes darkly that if there is any lesson to be learnt from Brexit, it is that "dreams of imperial glory can easily dazzle people into voting against their own interests" (Mondal 90).

Brexit, just like nationhood, freedom, and sovereignty, is a construct; the dying planet accidentally divided into the light and dark side is a catastrophe beyond political leanings. The events of the novel show how clinging to old grand narratives is an exercise in futility, an empty gesture feeding the egos of the elite at the price of the comfort of life (and sometimes even life itself) of people who must face this catastrophe. Looking back to good old times may bring solace, but it is so illusory that only the most deluded are tricked into believing that a repeat is possible. Kristian Shaw writes of false "national heritage ... and a mourning for the imperial past" (Shaw 18), which substitutes mourning 
for the ecologically viable past. Neither will be brought to life, no matter how much electricity is applied to their lifeless corpses.

The Last Day is insidious in its presentation of ecological catastrophe typical of the eco-thriller genre: whereas the reader may expect a disaster along the lines of the trope alluded to by Bulfin, in which scientists cannot convince governments that some undertaking would lead to the planet's destruction and the humanity is doomed, but deservedly so, this novel presents a planet-shifting change out of human control and, crucially, responsibility. The Earth stops spinning due to meteoric activity: nobody could have prevented it, nobody is in control but also-nobody is liable. Thus, the storyline of Hopper fighting the Great Enemy rings hollow; perhaps there is hope in connecting with people on the other side of the globe and overthrowing the dictatorship together, but all these attempts will not make the Earth spin again. The past is irretrievably lost, and the future is uncertain.

By situating Britain at the centre of the world again, The Last Day gives a platform to darker sentiments that could have inspired the pro-Brexit campaign. Far from seeing the leave-voters as disenfranchised people sending a desperate message to the establishment or as senile elders who confound their pastoral memories of youth with pre-EU Britain (like Ian McEwan does in his Brexit satire The Cockroach), Murray seems to suggest that the Brexiteers may have been driven by their desire to return to global power by any means possible, accepting such consequences as a fascist regime or imperial atrocities as collateral damage on their path to a truly Great (again) Britain.

All in all, with a slight substitution of "England" for "The Earth" in the following verse - and, at this point, both in The Last Day and in the contemporary British political discourse, England to all intents and purposes is the Earth-Murray's novel may be given a well-rounded poetic conclusion courtesy of "The News" by Jacob Polley (qtd. in Varty 63):

The moon's not sad; the sun won't worry.

Despite your suffering, England's still

And only some of us are sorry. 


\section{| Works Cited}

Andrews, Kehinde. The New Age of Empire: How Racism and Colonialism Still Rule the World. Penguin uK, 2021. E-book.

Barry, Aoife. "Britain Has Pride about Not Succumbing to Fascism in the 2oth Century-I'm Suggesting It Could Happen in the 21st." The Journal.Ie. 7 May 2020. https://jrnl.ie/5031116. Accessed 28 April 2021.

Bulfin, Ailise. "The Natural Catastrophe in Late Victorian Popular Fiction: 'How Will the World End?"' Critical Survey 27.2 (2015a): 81-101. https://doi.org/10.3167/cs.2015.270207

---. “'To Arms!': Invasion Narratives and Late-Victorian Literature.” Literature Compass 12.9 (2015b): 482-496. https://doi.org/10.1111/lic3.12253

Keep, C.J. "Fearful Domestication: Future-War Stories and the Organization of Consent, 1871-1914." An Interdisciplinary Critical Journal 23.3 (1990): 1-16.

Matin, A. Michael. "The Creativity of War Planners: Armed Forces Professionals and the Pre-1914 British Invasion-Scare Genre." ELH 78.4 (2011): 801-831.

---. “Gauging the Propagandist's Talents: William Le Queux's Dubious Place in Literary History. Part One." Critical Survey 32. 1/2 (2020): 79-98. https://doi.org/10.3167/cs.2019.112604

Mondal, Anshuman A. "Scratching the Post-Imperial Itch." Brexit and Literature: Critical and Cultural Responses. Ed. Robert Eaglestone. London and New York: Routledge, 2018. 82-91.

Mukherjee, Ankhi. "Migrant Britain.” Brexit and Literature: Critical and Cultural Responses. Ed. Robert Eaglestone. London and New York: Routledge, 2018. 73-81.

Murray, Andrew Hunter. The Last Day. London: Hutchinson, 2020.

O’Toole, Fintan. Heroic Failure: Brexit and the Politics of Pain. Head of Zeus, 2018. E-book.

Rau, Petra. "Autumn after the Referendum.” Brexit and Literature: Critical and Cultural Responses. Ed. Robert Eaglestone. London and New York: Routledge, 2018. 31-43.

Sanghera, Sathnam. Empireland: How Imperialism Has Shaped Modern Britain. Penguin UK, 2021. E-book.

Shaw, Kristian. "BrexLit.” Brexit and Literature: Critical and Cultural Responses. Ed. Robert Eaglestone. London and New York: Routledge, 2018. 15-30.

Tomlinson, Sally. Education and Race from Empire to Brexit. Bristol: Policy Press, 2019.

Turnnige, Sarah. "Neighbours' Horror as Racist 'Happy Brexit Day' Posters Put up in Norwich Tower Block." HuffPost UK. 2 Feb. 2020. https://tinyurl.com/happybrexitday. Accessed 28 April 2021. 
Varty, Anne. "Poetry and Brexit." Brexit and Literature: Critical and Cultural Responses. Ed. Robert Eaglestone. London and New York: Routledge, 2018. 59-65.

Wells, H.G. “The Star.” The Short Stories of H.G. Wells. London: Ernest Benn, 1957. 644-655.

\section{| Abstract}

JustynA JAJSzCZOK

\section{The Last Day and Brexit: Delusions of Future Past}

The paper aims to show how the traditions of science fiction and, above all, invasion literature provide the ideological background for reading Andrew Hunter Murray's The Last Day as a novel about Brexit. As it draws on anxious visions of the future, in which the enemy lurks around every corner, and the only salvation is complete isolation from the world, Murray's work is read here as a Brexit dream come true, in which Britain is once again great, independent and uncontaminated by foreign elements. By evoking the myths that focus only on glory and conveniently "forget" the dark sides of the empire, the novel demonstrates that the fantasies of the past are as distant as the fantasies of the future; the loss of the world that never was is reworked in The Last Day into the loss of ecologically viable planet.

Keywords: Brexit; eco-dystopia; imperial past; invasion literature; The Last Day

\section{| Abstrakt}

Justrna JAJSZCZOK

The Last Day (Ostatni dzień) i brexit. Złudzenia przyszłości i przeszłości

Artykuł ma na celu ukazać, w jaki sposób tradycje science fiction, a przede wszystkim literatury inwazji, stanowią ideologiczne tło dla lektury The Last Day Andrew Hunter Murraya jako powieści o brexicie. Opierając się na niepokojących wizjach przyszłości, w których wróg czai się za każdym rogiem, a jedynym ratunkiem jest całkowita izolacja od świata, książka Murraya jest tu odczytywana jako brexitowe spełnienie marzeń, w których Brytania znów jest wielka, niezależna i niezanieczyszczona obcym elementem. Przywołując mity, które koncentrują się wyłącznie na chwale i wygodnie „zapominają” o ciemnych stronach imperium, powieść 
pokazuje, że fantazje przeszłości są tak odległe jak fantazje przyszłości, a utrata świata, którego nigdy nie było, staje się analogią do utraty planety, na której wciąż możliwe jest życie.

Słowa kluczowe: brexit; ekodystopia; imperialna przeszłość; literatura inwazji;

The Last Day

\section{| About the Author}

Justyna Jajszczok, PhD, is an Assistant Professor at the Institute of Literary Studies, University of Silesia in Katowice, Poland. Her research interests include Victorian science and fiction, future-war and invasion narratives, and infection literature, with a particular focus on metaphors of science and medicine in literary and cultural discourse. In 2019, she co-edited (with Aleksandra Musiał) a volume in the Routledge Studies in Cultural History series devoted to the body and the corporeal in various historical, cultural and literary contexts. In 2021, together with Alicja Bemben, she guest-edited a special issue of the World and Word journal devoted to science in popular culture.

E-mail: justyna.jajszczok@us.edu.pl

ORCID: 0000-0003-4034-4054 